Research Article

\title{
Relationship between Knowledge, Attitude and Behavior of Postnatal Woman Toward Participation in Permanent Contraception
}

\author{
Hubungan Pengetahuan, Sikap dan Perilaku Ibu Pascasalin terhadap \\ Partisipasi Kontrasepsi Mantap Perempuan
}

\author{
Jhon Heriansyah, Azhari' ${ }^{1}$, Firmansyah Basir ${ }^{1}$, Theodorus ${ }^{2}$ \\ ${ }^{1}$ Department Obstetrics and Gynecology \\ ${ }^{2}$ Medical and Health Research Unit \\ Faculty of Medicine Universitas Sriwijaya/ \\ Dr. Mohammad Hoesin Hospital \\ Palembang
}

\begin{abstract}
Objective: To investigate the association between knowledge, attitude, and behavior towards participation in permanent contraception and describe factors that could affect participation of permanent contraception in women in RSMH Palembang.

Methods: This case control study was conducted at the Department of Obstetrics and Gynecology, Dr. Mohammad Hoesin Hospital/ Faculty of Medicine, Universitas Sriwijaya, Palembang, during the period of June 2016 to December 2016. Sample of the cases group was woman who agreed to use permanent contraception while control sample was women who refuse to use permanent contraception. Data were collected using a questionnaire. Statistical analysis was performed using SPSS.

Results: There was a significant association between attitude, behavior, husband support, and disease complications with participation of permanent contraception. Factors that influenced participation of permanent contraception in woman in RSMH Palembang include husband support and behavior.

Conclusion: Factors that influence the participation of women in RSMH safe contraception Palembang include support for her husband and behavior.

[Indones J Obstet Gynecol 2018; 6-1: 39-44]

Keywords: family planning, participation, permanent contraception
\end{abstract}

\begin{abstract}
Abstrak
Tujuan: Mengetahui hubungan antara pengetahuan, sikap dan perilaku terhadap partisipasi kontrasepsi mantap dan mendeskripsikan faktor-faktor yang dapat mempengaruhi partisipasi kontrasepsi mantap perempuan di RSMH Palembang.

Metode: Penelitian kasus kontrol ini dilakukan di Departemen Obstetri dan Ginekologi di Rumah Sakit Dr. Mohammad Hoesin/ Fakultas Kedokteran Universitas Sriwijaya Palembang sejakJuni 2016 hingga Desember 2016. Sampel kasus adalah perempuan yang setuju menggunakan kontrasepsi mantap sedangkan sampel kontrol adalah perempuan yang menolak kontrasepsi mantap. Data dikumpulkan dengan menggunakan kuesioner. Analisis statistik dilakukan dengan program SPSS.
\end{abstract}

Hasil: Ada hubungan bermakna antara sikap, perilaku, dukungan suami, usia, dan penyakit penyulit dengan partisipasi kontrasepsi mantap. Faktor-faktor yang mempengaruhi partisipasi kontrasepsi mantap perempuan di RSMH Palembang antara lain dukungan suami dan perilaku.

Kesimpulan: Faktor-faktor yang mempengaruhi partisipasi kontrasepsi mantap perempuan di RSMH Palembang antara lain dukungan suami dan perilaku.

[Maj Obstet Ginekol Indones 2018; 6-1: 39-44]

Kata kunci: keluarga berencana, kontrasepsi mantap, partisipasi

Correspondence: Jhon Heriansyah, jhon.heriansyah@gmail.com

\section{INTRODUCTION}

Family planning is a program aiming to help married couples avoiding unwanted births, getting wanted pregnancy, setting interval between pregnancies and birth, and determining the number of children in a family. 1,2

According to the 2010 Population Census, the population of Indonesia is 237.556 .363 peoples. Population Growth Rate during period of 20002010 is $1.49 \%$, this was higher than growth rate in $1990-2000$ which was $1.45 \%$. The total area of Indonesia is estimated to be $1,910,931 \mathrm{~km}^{2}$, whereas the population density is $124 \mathrm{~km}^{2}$. Based on these data, Indonesia is the world's fourth most populous country. ${ }^{3}$

New paradigm of National Family Planning Program has changed its vision from "Norm of Small, Happy and Prosperous Family" (NKKBS) became a vision to actualize "Quality Family 2015". Quality family is a prosperous, healthy, and independent family with ideal number of children, 
forward-looking, responsible, harmonious and devoted to God Almighty. ${ }^{2}$

To achieve the objectives of National Medium Term Development Plan (RPJMN 2010-2014) and changing of strategic environment and to achieve target of Millennium Development Goals (MDGs) which is embody access to reproductive health by 2015, then provision of quality Long Term Contraception Method (LTCM) is expected to increase number LTCM participation by couples of childbearing age at all stages of the family, and hopefully national Total Fertility Rate (TFR) will decline. ${ }^{4,5}$

Use of LTCM in Indonesia is still relatively low. Based on Indonesian Demographic Health Survey, participant of LTCM decreased from 14.6\% (2002/2003) to $10.9 \%$ (2007). Participation of Intra Uterine Device (IUDs) tend to decrease from $8.1 \%$ to $6.2 \%$ (IDHS 2002/2003) and fell further to just $4.9 \%$. Subdermal contraception (AKBK) also tend to decline more than 50 percent, from 6 percent to $2.8 \%$. Although Woman Operative Methods (MOW) had increased by $3.7 \%$, participation rate dropped to 3\%. Man Operative Method (MOP) had stagnated at $0.4 \%$ and participation rate dropped to $0.2 \%$. Pattern of contraceptive use in Indonesia is still dominated by hormonal and short term contraception. .-7 $^{5-1}$

Decision to participate in family planning is influenced by many factors such as knowledge, attitude and behavior towards contraception as well as other factors such as family support, environment, religion and customs regulations. To increase the use of MOW as a contraceptive method of choice, it is necessary to know factors that influence the decision making of contraceptive use in woman. ${ }^{1,2}$

\section{METHODS}

This was an observational case-control study. The study was conducted at Obstetrics and Gynecology Department of Dr. Mohammad Hoesin Hospital/ Faculty of Medicine, Universitas Sriwijaya, since June 2016 to December 2016. Case sample was postnatal women who have agreed and use permanent contraception in RSMH Palembang, while control group was postnatal women who refuse to use permanent contraception. Patients who were obese or overweight, have pelvic abnormalities such as adhesions and infections, or have severe illness (cardiorespiratory problems) were excluded from analysis.

Patients who met inclusion criteria were given an explanation about the study and signed informed consent. Then patients were asked to fill out questionnaires that have been provided.

Distribution and frequency of data presented in the form of textural and tables. Data were analyzed using Chi-square test or Fisher and logistic regression analysis. Data is processed by SPSS (Statistical Package for the Social Science) for Windows.

\section{RESULTS}

Table 1. Characteristics of Study Subjects

\begin{tabular}{|c|c|c|c|c|}
\hline \multirow{3}{*}{ Variables } & \multicolumn{4}{|c|}{ Persistent Contraception } \\
\hline & \multicolumn{2}{|c|}{ Yes } & \multicolumn{2}{|c|}{ No } \\
\hline & $\mathbf{n}$ & $\%$ & $\mathbf{n}$ & $\%$ \\
\hline \multicolumn{5}{|l|}{ Age } \\
\hline > 35 yo & 32 & 58.2 & 20 & 36.4 \\
\hline$\leq 35$ yo & 23 & 41.8 & 35 & 63.6 \\
\hline \multicolumn{5}{|c|}{ Number of children } \\
\hline$>3$ & 27 & 49.1 & 24 & 43.6 \\
\hline$\leq 3$ & 28 & 50.9 & 31 & 56.4 \\
\hline \multicolumn{5}{|l|}{ Education } \\
\hline Uneducated & 6 & 10.9 & 3 & 5.5 \\
\hline Elementary school & 18 & 32.7 & 15 & 27.3 \\
\hline Junior high school & 12 & 21.8 & 11 & 20.0 \\
\hline Senior high school & 15 & 27.3 & 19 & 34.5 \\
\hline University & 4 & 7.3 & 7 & 12.7 \\
\hline \multicolumn{5}{|l|}{ Occupation } \\
\hline House wife & 48 & 87.3 & 42 & 76.4 \\
\hline Civil servant & 1 & 1.8 & 3 & 5.5 \\
\hline Trader & 3 & 5.5 & 5 & 9.1 \\
\hline Farmer & 1 & 1.8 & 1 & 1.8 \\
\hline Private company & 2 & 3.6 & 4 & 7.3 \\
\hline \multicolumn{5}{|l|}{ Religion } \\
\hline Non Muslim & 0 & 0 & 1 & 1.8 \\
\hline Muslim & 55 & 100 & 54 & 98.2 \\
\hline \multicolumn{5}{|c|}{ Social Economic Status } \\
\hline$\leq \mathrm{UMR}$ & 42 & 76.4 & 36 & 65.5 \\
\hline > UMR & 13 & 23.6 & 19 & 34.5 \\
\hline
\end{tabular}




\begin{tabular}{lcccc} 
Assurance & & & & \\
Askin & 11 & 20.0 & 7 & 12.7 \\
BPJS & 20 & 36.4 & 17 & 30.9 \\
Jamkesmas & 1 & 1.8 & 2 & 3.6 \\
Jamsoskes & 14 & 25.5 & 22 & 40 \\
KIS & 8 & 14.5 & 6 & 10.9 \\
None & 1 & 1.8 & 1 & 1.8 \\
Tribe & & & & \\
Sumatera & 38 & 69.1 & 45 & 81.8 \\
Non Sumatera & 17 & 30.9 & 10 & 18.2 \\
Disease complication & & & & \\
Yes & 30 & 54.5 & 17 & 30.9 \\
No & 25 & 45.5 & 38 & 69.1 \\
\hline \hline
\end{tabular}

During study period we included 110 samples consisted of 55 postnatal women who agreed and used permanent contraception in RSMH Palembang and 55 postnatal mother who refused to use permanent contraception. Patient characteristics were shown in Table 1.
We found a significant association between age and disease complications with participation of permanent contraception. Age $>35$ years and disease complication was 2,435 times and 2,682 times respectively more possible to participate in permanent contraception ( $p<0.05)$. Number of children, education and socio-economic status was not significantly associated with participation of permanent contraception (Table 1).

Based on recapitulation of responses to questionnaires about knowledge (Gutzman Scale), attitude (Likert Scale) and behavior (Gutzman Scale) we get a category of knowledge, attitudes and behavior of respondents as shown in Table 3.

Based on logistic regression test (Table 5), it can be concluded that husband's support significantly influence participation of permanent contraception $(\mathrm{OR}=188.709, \mathrm{p}$ value $=0.000)$. In addition, behavior also significantly affects participation of permanent contraception $(\mathrm{OR}=10.260$, $\mathrm{p}$ value $=$ 0.023). Knowledge ( $O R=0.380, p$ value $=0.223$ ) and behavior (OR $=4.196$, $\mathrm{p}$ value $=0.497)$ did not affect participation of permanent contraception.

Table 2. Analysis of Correlation between Subjects Characteristics and Participation of Permanent Methods

\begin{tabular}{|c|c|c|c|c|c|}
\hline \multirow{2}{*}{ Characteristics } & \multicolumn{2}{|c|}{ Participation of permanent methods } & \multirow{2}{*}{ Total } & \multirow{2}{*}{$\begin{array}{c}\text { OR* }^{*} \\
\text { (CI 95\%) }\end{array}$} & \multirow{2}{*}{ p value* } \\
\hline & Yes & No & & & \\
\hline \multicolumn{6}{|l|}{ Age } \\
\hline$>35$ yo & 32 & 20 & 52 & \multirow{2}{*}{2.435} & \multirow{2}{*}{0.036} \\
\hline$\leq 35$ yo & 23 & 35 & 58 & & \\
\hline \multicolumn{6}{|c|}{ Number of children } \\
\hline$>3$ & 27 & 24 & 51 & \multirow{2}{*}{1.246} & \multirow{2}{*}{0.702} \\
\hline$\leq 3$ & 28 & 31 & 59 & & \\
\hline \multicolumn{6}{|l|}{ Education } \\
\hline Low & 36 & 29 & 65 & \multirow[t]{2}{*}{1.699} & \multirow[t]{2}{*}{0.245} \\
\hline High & 19 & 26 & 45 & & \\
\hline \multicolumn{6}{|l|}{ Social Economic } \\
\hline$\leq \mathrm{UMR}$ & 42 & 36 & 78 & \multirow{2}{*}{1.705} & \multirow{2}{*}{0.294} \\
\hline > UMR & 13 & 19 & 32 & & \\
\hline \multicolumn{6}{|c|}{ Disease complication } \\
\hline Yes & 30 & 17 & 47 & \multirow{2}{*}{2.682} & \multirow{2}{*}{0.021} \\
\hline No & 25 & 38 & 63 & & \\
\hline Total & 55 & 55 & 110 & & \\
\hline
\end{tabular}

*Uji Chi Square, $p$ value $=0.05$ 
Table 3. Characteristics Analysis of Factors Affecting Participation of Permanent Contraception

\begin{tabular}{lcccc}
\hline \multirow{2}{*}{ Variables } & \multicolumn{4}{c}{ Participation of } \\
& \multicolumn{3}{c}{ permanent contraception } \\
\cline { 2 - 5 } & n & \% & n & No \\
\cline { 2 - 5 } Knowledge & & & & \\
Good & 47 & 85.5 & 46 & 84.5 \\
Bad & 8 & 14.5 & 9 & 15.5 \\
Attitude & & & & \\
Good & 48 & 85.5 & 6 & 10.9 \\
Bad & 7 & 14.5 & 49 & 89.1 \\
Behaviour & & & & \\
Good & 51 & 92.7 & 18 & 32.7 \\
Bad & 4 & 7.3 & 37 & 67.3 \\
Husband Support & & & & \\
Yes & 54 & 98.2 & 4 & 7.3 \\
No & 1 & 1.8 & 51 & 92.7 \\
\hline \hline
\end{tabular}

Table 4. Factors Affecting Participation of Permanent Contraception

\begin{tabular}{lcccc}
\hline \hline \multirow{2}{*}{ Variables } & \multicolumn{2}{c}{ Unadjusted* $^{*}$} & \multicolumn{2}{c}{ Adjusted $^{* *}$} \\
\cline { 2 - 5 } & OR & p value & OR & p value \\
\hline Support & 688.5 & 0.000 & 188.709 & $\mathbf{0 . 0 0 0}$ \\
Behaviour & 56.00 & 0.000 & 10.260 & 0.023 \\
Attitude & 26.208 & 0.000 & 4.196 & 0.223 \\
Knowledge & 1.149 & 1.000 & 0.380 & 0.497 \\
\hline \hline
\end{tabular}

${ }^{*}$ Logistics regression, $p$ value $=0.05$

\section{DISCUSSION}

Permanent contraception is any action on woman's fallopian tubes or man's vas deferens which resulted on infertility, based on request of husband or wife. ${ }^{1,2,8}$

Age of most women in case group was $>35$ years and there is a relationship between age and participation of safe contraception (OR $=2.435$; $\mathrm{p}=0.036$ ). Results of this study are not much different from study by Sekar Mutiara in 2010. They found that most women who agreed to use permanent methods was $>30$ years old, but it was only a descriptive study without assessing the relationship between age and the participation of permanent contraception. This result was in contrast to research by Herlinawati et al in 2012, age of women who choose permanent contraception mostly was 20-35 years and they did not found relationship between age and selection of permanent contraception (OR $=2.051$; $\mathrm{p}=0.152$ ). Type of contraception should be adapted to stage of reproductive period. Age $>35$ years is an old reproductive period (36-45 years) and an end of fertility period, so at the age of $>35$ years women are more likely to approve permanent contraception.6,9-11

Women who agreed (50.9\%) or rejected to (56.4\%) participated in permanent contraception mostly had $\leq 3$ children, the proportion was lower in rejected group. There is no relationship between number of children with participation of permanent contraception $(O R=1.246 ; p=0.702)$. These results was in contract with study by Herlinawati et al (2012) which found that woman who approve or reject permanent contraception mostly had $>3$ children with higher proportions in woman who agree to participate in permanent contraception (OR $=13.254 ; \mathrm{p}=0.001)$. Difference in this study may be due to the proportion of number of children $>3$ and $\leq 3$ in women who agree to use permanent contraception was almost the same. ${ }^{9,10,11}$

Most subjects in both groups have incomes $\leq$ UMR $(76.4 \%$ in case and $65.5 \%$ in control group). There is no correlation between economic status with participation of permanent contraception $(\mathrm{OR}=1.705 ; \mathrm{p}=0.294)$. Results of this study were not much different from study by Sekar Mutiara in 2010. Influence of socio-economic status in family planning is correlated with opportunity or ability to obtain family planning facilities.6,12-14

Majority of women who choose contraception have low education (64.46\%). There is no relationship between education and participation of permanent contraception $(\mathrm{OR}=1.699 ; \mathrm{p}=$ 0.245). These results were in contrast to studies conducted by Ismail and Sisca in 2012 in Karangampel 1 village Kidul District Indramayu. They found that women who agree to use permanent contraception had higher education $(73.68 \%)$ and they found an association between level of education and selection of permanent contraception (OR $=2.520 ; \mathrm{p}=0.020)$. A similar result was reported by Herlinawati et al (2012). Different result found in this study may be due to low knowledge of permanent contraception in both case and control group. ${ }^{13,15,16}$ 
Most subjects in this study mostly had disease complications. There was a relationship between disease complications with participation of permanent contraception. Women with disease complications 2,682 times more likely to participate in permanent contraception $(\mathrm{OR}=$ 2.682; $p=0.021$ ). These results are in contrast to studies conducted by Sekar which found that most woman $(86 \%)$ who had disease history refused to participate in permanent contraception. Results of this study supported by Pratama (2005) which found a significant association between disease history with use of permanent contraception (OR $=11.3 ; \mathrm{p}=0.014 ; 95 \% \mathrm{CI}: 1.360$ to 94.248 ). Hormonal contraceptive use is contraindicated in patients with disease complications so they prefer to use permanent contraception.

We did not find any relationship between knowledge and participation of permanent contraception. Results of this study were not much different from study by Herlinawati et al (2012) who also found no correlation between knowledge with participation of permanent contraception in Dr. Pirngadi hospitals (OR $=1.850 ; \mathrm{p}=0.397$ ). Results of this study was different from results of study conducted by Ismail and Sisca in 2012 in Karangampel village Kidul District Indramayu. They found that women with good knowledge 2.474 times more likely to choose permanent contraception. Woman who has good knowledge may refuse permanent contraception due to other factors such as husband support or a number of children.

There is a significant relationship between attitude with participation of permanent contraception. This result was consistent with study by Herlinawati et al (2012) which show a significant association between attitudes and participation of permanent contraception in Dr. Pirngadi hospitals $(\mathrm{OR}=8.255 ; \mathrm{p}=0.016)$. In this study behavior was 56 times more likely to affect participation of permanent contraception.

Logistic regression analysis showed that husband's support was the most important factors that affect participation of permanent contraception. Husband support was 188.7 times more likely to affect participation of permanent contraception. Results of this study is supported by study by Herlinawati et al (2012) which showed a significant relationship between family support with participation of permanent contraception in Dr. Pirngadi hospitals $(\mathrm{OR}=12.016 ; \mathrm{p}=0.001)$.
Responsibility of reproductive health care, especially in the use of contraceptives predominantly done by woman, although in the decision making process men are involved, men are tend to be passive. ${ }^{17,18}$

Husband's participation in family planning programs and reproductive health care is an important factor. This participation will be achieved if various information relating to it always available. We all know that low participation of men/husbands in family planning and reproductive health is caused by limited information, especially for couples. $6,17,18$

Inability to communicate in decision making process placing housewife in low bargaining position, so that their needs and desires is difficult to fulfilled. Decisions are more likely dominated by interests of her husband; even if the decision involves issues relating to women's live such as reproductive health problem. ${ }^{19}$

In this study, husband's support was an important factor. 98.2\% woman who participate in permanent contraception reported that they received husband's support, meanwhile in woman who rejected to use permanent contraception 92.7\% did not received husband's support.

\section{CONCLUSION}

There was a significant relationship between attitude, behavior, age and disease complication with participation of permanent contraception. Factors that influence the participation of women in RSMH safe contraception Palembang include support for her husband and behavior.

\section{REFERENCES}

1. Irianto K. Pelayanan Keluarga Berencana Dua Anak Cukup. Bandung: Alfabeta; 2014: 8-10.

2. Yuhedi LT, Kurniawati T. Buku Ajar Kependudukan dan Pelayanan Keluarga Berencana. Jakarta: EGC; 2011: 21-6.

3. Profil Hasil Pendataan Keluarga Tahun 2011. Jakarta: Badan Kependudukan dan Keluarga Berencana Nasional Direktorat Pelaporan dan Statistik; 2011: 14-20.

4. Setyorini A. Kesehatan Reproduksi dan Pelayanan Keluarga Berencana. Bogor: In Media; 2014: 17-22.

5. Asih L, Oesman H. Faktor yang Mempengaruhi Pemakaian Kontrasepsi Jangka Panjang. Jakarta: Puslitbang KB dan Kesehatan Reproduksi BKKBN; 2009: 33-8.

6. Nasution SL. Faktor - Faktor yang Mempengaruhi Penggunaan MKJP di Enam Wilayah Indonesia. Jakarta: Puslitbang KB dan Keluarga Sejahtera BKKBN; 2011: 55-62. 
7. Alemayehu M, Belachew T, Tilahun T. Factors associated with utilization of long acting and permanent contraceptive methods among married women of reproductive age in Mekelle town, Tigray region, north Ethiopia. BMC pregnancy and childbirth. 2012; 12: 1-9.

8. Sulistyawati A. Pelayanan Keluarga Berencana, Jakarta: Salemba Medika; 2011: 26-8.

9. Priyoto. Teori Sikap dan Perilaku dalam Kesehatan. Yogyakarta: Nuha Medika. 20114-22.

10. Green LW, Iverson DC. School Health Education. Ann. Rev. Public Health. 1982; 3: 321-38.

11. Grady T, Cynthia D. Does a history of unintended pregnancy lessen the likelihood of desire for sterilization reversal? J Women's Health, 2013; 22(6): 501-6.

12. Eliminating forced, coercive and otherwise involuntary sterilization: an interagency statement, OHCHR, UN Women, UNAIDS, UNDP, UNFPA, UNICEF and WHO. 2014: 3-8.

13. The Respond Project. Synthesis of Female Sterilization Literature Review. USAID. 2013: 1-7.
14. Borrero R, Sonya D. Racial variation in tubal sterilization rates: role of patient-level factors. Fertil Steril, 2011; 95(1): 17-22.

15. Factors Influencing Sterilization Use and Outcomes from Contraceptive Sterilization: Global Issues and Trends. Engender Health. 2002: 107-21

16. Azwar S. Sikap Manusia Teori dan Pengukurannya, Ed 2, Yogyakarta, Pustaka Pelajar. 1995: 10-6.

17. Lawrence RE. Factors influencing physicians advice about female sterilization in USA: a national survey. Hum Reprod. 2011; 26(1): 106-11.

18. Machado, Katia MM, Bernarda A, Ludermir, Da Costa AM. Changes in family structure and regret following tubal sterilization. Cad. Saúde Pública. 2005; 26(1): 1768-77.

19. Reichwein J, Vaid W. What obstacles do rural Indian women face when attempting to end an unwanted pregnancy? Research Brief: Marie Stopes Int. 2013; 001: 1-6. 